\title{
中枢神経胚細胞腫瘍治療の基本方針
}

西川亮

\section{Some Principles for the Treatment of Central Nervous System Germ Cell Tumors}

by

Ryo Nishikawa, M.D.

from

Department of Neurosurgery, Saitama Medical School

Although the optimum treatment of intracranial germ cell tumors remains controversial, there are some basic underlying principles. 1) It is important to confirm the histological type of the tumors by biopsy or extirpation. 2) The appropriate extent of surgery for germinoma still remains to be discussed. The reliability of endoscopic biopsy should be compared with the results of the definite pathology after open biopsy or extirpation of the lesion. 3) In germinoma, it is not necessary to irradiate the whole spine. A reduced-volume radiotherapy such as whole-ventricular irradiation, plus chemotherapy should replace craniospinal radiotherapy to avoid the late sequelae of largevolume radiotherapy, such as impairment of endocrinological function or neurocognitive development. Focal irradiation would lead to an increased risk of recurrence. 4) Chemotherapy alone without irradiation is not sufficient to cure germinoma patients. 5) Neoadjuvant chemo-radiotherapy followed by complete excision of the residual tumors should be considered in patients with non-germinomatous germ cell tumors.

(Received September 16, 2005; accepted October 31, 2005)

Key words : germinoma, germ cell tumors, chemotherapy, radiotherapy

\section{Jpn J Neurosurg（Tokyo） $15: 171-176,2006$}

\section{はじめに}

中枢神経胚細胞腫煬には多彩な組織型が含まれている が，これを 3 群に分ける分類が提唱さ机ている（Table $1)^{11)}$.この分類は, 多数の症例の生存期間解析を基にし た日本独自の成果である。欧米では germinoma/non-germinomatous germ cell tumor, あるいは secreting/nonsecreting germ cell tumor という 2 群への分類が一般的 であるが，これらの分類ではきめ細かな治療法の選択が できない ${ }^{12)}$ ，中枢神経胚細胞腫瘍の治療は, 1980 年以前 は放射線照射が主体であったが, 1980 年代に化学療法が 導入され治療成績が向上した. 1990 年代前半の治療成績
としては，5 年生存率が germinoma 95\%, 予後中間群約 $70 \%$, 予後不良群約 $20 \%$ あるいはそ机以下と報告さ机て いる ${ }^{11)}$. したがって 1990 年代後半からの課題は, すで に放射線照射単独によってもおよそ90\%の症例が治癒 可能となっている germinoma においては, 治癒率を維持 しつつ, 治療による障害, 特に放射線照射による障害を 軽減すること, また予後中間群と不良群においては生存 期間のさらなる延長を図ることと総括された。この課題 の達成を目的として, 1995 年から厚生労㗢省がし研究助 成金による研究班が組織された。 2005 年の時点における 成果は，5 年生存率において germinoma $98 \%$, 予後中間 群 $94 \%$, 予後不良群 $64 \%$ である（松谷雅生, unpublished

埼玉医科大学脳神経外科 $/ \overline{\mathrm{T}} 350-0495$ 入間郡毛吕山町毛吕本鄉 38 〔連絡先：西川 亮〕

Address reprint requests to: Ryo Nishikawa, M.D., Department of Neurosurgery, Saitama Medical School, 38 Morohongo, Moroyama-machi, Iruma-gun, Saitama 350-0495, Japan 
Table 1 Therapeutic classification of intracranial germ cell tumors

\begin{tabular}{l}
\hline Group w/good prognosis \\
germinoma, pure \\
mature teratoma \\
Group w/intermediate prognosis \\
germinoma w/STGCs \\
immature teratoma \\
teratoma w/malignant transformation \\
mixed tumors composed mainly of \\
germinoma or teratoma \\
Group w/poor prognosis \\
choriocarcinoma \\
yolk sac tumor \\
embryonal carcinoma \\
mixed tumors composed mainly of choriocarcinoma, \\
yolk sac tumor, or embryonal carcinoma \\
\hline
\end{tabular}

data).本稿では，この研究班の成果を踏まえたうえで, 中枢神経胚細胞腫瘍治療において押さえておかなければ ならないポイントの幾つかについて，現時点での考え方 を概説する。

\section{中枢神経胚細胞腫瘍においては 手術が必要である}

いわゆる診断的照射は，組織型によってきめ細かな治 療方針を選択する必要があることが認識され，また手術 が十分に安全に行われるようになった現在においては, すでに過去のものである，日本脳腫瘍学会による調査に よれば，日本脳神経外科学会専門医認定制度 A 項病院に おいて, 1997〜2001 年までの 5 年間に行われた松果体部 腫愓手術 455 例のうちの手術死亡は 3 例 $(0.7 \%)$ である (日本脳腫瘍学会による未発表デー夕)。これは，集計さ れた全開頭脳腫瘍摘出手術 26,495 例における手術死亡 率 $0.5 \%$ とほぼ変わりがない．また，手術による組織確 認を行わなかった場合, non-germinomatous germ cell tumor を germinoma と誤る率は 20〜30\%であり, 組織診 断未確認のまま治療した germinoma は, 組織確認のうえ 治療した germinoma よりも 10 年生存率が悪い傾向にあ ることも知られている ${ }^{10)}$. 腫瘍マーカーの測定は，診断 や治療方針の選択や，治療経過の判定にも重要な役割を 果たす。しかし， $\alpha$-fetoprotein や human chorionic gonadotropin- $\beta$ (HCG- $\beta$ ) が陰性でも germinoma とは限らず, immature teratoma や embryonal carcinoma，あるいはそれ らを含む mixed tumor である可能性がある. Placental alkaline phosphatase ${ }^{19)}$ や $\mathrm{c}-\mathrm{Kit}^{13)}$ が有意に高值である腫 瘍は germinoma 成分を含んでいると考えられるが,これ
Table 2 Relapse in patients with germinomas with reducing irradiation volume (adapted from Rogers SJ, et al. 2005)

\begin{tabular}{lccc}
\hline \multicolumn{1}{c}{ Irradiated volume } & Patients & Relapse & $\%$ \\
\hline Craniospinal + boost & 343 & 13 & 4 \\
Whole brain of whole ventricle + boost & 278 & 21 & 8 \\
Focal & 133 & 31 & 23 \\
\hline
\end{tabular}

らは non-germinomatous な成分の混入に関して情報を もたらすものではない．画像所見についても然りであ $ろ^{7)}$.

\section{Germinoma の手術は生検で十分か, あるいはあくまで全摘を目指すべきか}

これは摘出量が予後と相関しているかどうかに掛かっ ている，生検だけにした場合も全摘の場合も，治療成績 は同様であるとの報告がある17)。しかし，germinoma を 含む mixed tumor に対して少量の生検を行った場合に, 例えば immature teratoma 成分の混入等を見逃す可能性 があるが，これが実際に治療成績にどの位影響するのか について結論を出すためには多数例の蓄積が必要であろ う。最近進歩著しい神経内視鏡による生検に対しても同 様の検討が必要である，中枢神経胚細胞腫瘍に対しての 内視鏡生検の診断率，すなわち何籄所から生検を行った ならば十分に許容できるエラーの下に診断が下しえる か，内視鏡生検手技の危険率，また最終的には内視鏡生 検で診断した症例の生存期間の評価等について, 多数症 例を集めた科学的なエビデンスの集積が急務である.

\section{Germinoma に対する放射線治療の照射範囲 について} 一全脳照射か全脳室照射か，あるいは局所照射か一

Germinoma は放射線感受性が高いことはよく知られ ている，一方，放射線照射には障害の危険性があること も知られている．では，治療成績を落とさない範囲で放 射線照射の範囲と線量をどこまで低隇できるかという問 題である.

照射方法別の治療成績について過去の文献を渉殍し解 析した結果が報告されている15) (Table 2)，この表をみる と，まず局所照射では $23 \% の$ 再発率が報告され，germinoma は局所照射では制御されないことがわかる，一般 に局所照射の場合の再発は照射野外にみられることが知 られていて，この腫瘍の播種を起こしやすい性格を反映 しているものと考えられる，前述の厚生労働省研究班の 
経験においても, 腫瘍辺縁から $1 \mathrm{~cm}$ の安全域を持たせた 範囲に照射した場合の germinoma の再発率が 33.3\%, 腫 瘍辺縁から $2 \mathrm{~cm}$ の安全域を持たせた範囲に照射した場 合の再発率は $18.8 \%$ で，やはり局所照射では，たとえ多 少のマージンを取って照射したとしても, 照射野外に残 存する germinoma からの再発が少なくないことが示さ れている (松谷雅生, unpublished data)。こ扎は, MRI 上では腫煌の存在が検出されていなくても, 内視鏡で観 察すると第三脳室底などに小さな播種巣が存在すること からもうなずける20).

一方, 全脳全脊咀照射症例の再発率は $4 \%$ ときわめて 少なく優れた治療効果を示している (Table 2). Germinoma に対する全脳全脊䯣照射による治療成績の報告と しては，例えばドイツに扮ける前向き多施設共同研究 MAKEI 83/86/89 を挙げることができる ${ }^{4)}$. 全脳全脊䯣 $30 \mathrm{~Gy}$ に加えて局所 $15 \mathrm{~Gy}$ を照射した結果，5年間 relapse-free survival は 88.8\%, 5 年間 overall survival は $92.0 \%$ と報告されている。ほぼ満足すべき治療成績であ ろう。しかし, germinomaにおいては脊䯣照射が必ずし も予後改善に寄与していないことは, 多数例の統計学的 解析によって証明されている ${ }^{18)}$ ，脊髄照射を行わない場 合, 全脳照射に局所照射を追加照射した症例も, 全脳室 照射に局所照射を追加照射した症例も再発率に相違はな く $8 \%$ である ${ }^{15)}($ Table 2).したがって, 治療成績の観点か らは全脳照射ではなく, 大脳皮質を外して全脳室照射に までは照射野を絞孔るようである。では, 全脳照射では なく全脳室照射でとどめた場合, 放射線照射による障害 はどの程度低減されるのであろうか.

全脳照射による障害としては, 内分泌学的障害と高次 機能障害が代表的なものである。放射線照射による内分 泌学的障害の発生は古くから知ら机ている。肾白血病 における予防全脳照射の場合の解析であるが，障害は線 量に依存し， $24 \mathrm{~Gy}$ であれば成長ホルモンの分泌障害は 軽度であり，24 Gy を超えるとその障害は重くなるとい う報告がある ${ }^{6)}$. 全脳室照射に打いては, 第三脳室底の 漏斗陥山等を十分に照射野に含めることが重要であるか ら，視床下部脳下垂体系も照射野に含まれる。したがっ て, 内分泌学的障害を考える際には, 照射野よりも線量 の多鿒が問題となる。 $24 \mathrm{~Gy}$ の全脳室照射によって治療 した germinomaに扔いて, 治療前から存在した内分泌学 的異常は改善しなかったようだが, 治療によって新たに 出現，あるいは悪化した障害はなかったと報告されてい $る^{2)}$ 。ただし，この報告は全脳室照射で治療した症例数が 6 例と少なく, 厚生労働省研究班による多数例の報告が 俟たれる。
全脳照射による高次機能障害は, 18〜24 Gy の線量で も mild で遅発性ではあるが障害が出る可能性があると 報告されている，障害は年少児ほで顕著であり, 線量が 少ない場合は注意力散漫と記銘力障害が主体で, 高線量 では認知障害を生じるとされている ${ }^{16)}$ ，高度の認知障害 であ机ば発見は比較的容易であるが, 注意力散漫や記銘 力障害を呈している場合は，それを見落とさないことが 必要である. 先の MAKEI 研究では, $52 / 56$ (92.8\%) が 学校在学中, あるいは卒業し, 35/56 (62.5\%) が degree を得たので，高次機能の面でも全脳照射には問題は少な いと報告されている(ここでいう degree が大学卒業を意 味するとすると相当に高い数字である）が，具体的な高 次機能の検査は行われていない, 一方, 全脳室照射例の 報告では, WAIS 知能検查を行っても治療後の低下は認 められていない2)14). ただし高次機能については，どの ような検査を行えば鋭敏に障害を検出できるか十分な検 討が必要であり，また長期間にわたる追跡も重要である。

\section{Germinoma であっても化学療法のみでは 制御できない}

Germinomaは化学療法にも感受性がよいことが知ら れている、そこで放射線照射による障害を避けるために， 化学療法の夕で治療を行った場合の成績はどうであろう か. 米国を中心とした国際共同研究において, bleomycin + etoposide + carboplatin による BEP 療法を 6 コー ス， $\mathrm{CR}$ を達成しない場合は途中から cyclophosphamide を加光るという方法で治療した成績が報告されている. 7/71 (9.9\%) の患者が治療死したという強力な治療で あったが, germinoma 症例の $82 \%$ $\mathrm{CR}$ を達成してい る。しかし， 31 力月の追跡で $49 \% も の$ 症例が再発を呈 している3). 日本からも同様に germinomaの 7 例を化学 療法（BEP 療法，または cisplatin+etoposide）のみで治 療した結果，全例が $\mathrm{CR}$ を達成したが，5/7 例（71\%） が再発したと報告されている ${ }^{9)}$. 以上のように, 現在の 化学療法レジメンでは, 放射線照射なしで germinoma 治癒させることはできない.

\section{欧米の動向}

欧米の最近の動向について紹介する. French Society for Pediatric Oncology (SFOP) と International Society of Pediatric Hematology and Oncology (SIOP) による臨床試 験は, germinomaに対しては carboplatin, ifosfamide, etoposide による化学療法に局所照射 $40 \mathrm{~Gy}$ を併用する方法 
Table 3 Treatment protocol for intracranial germ cell tumors proposed by the Japanese Pediatric Brain Tumor Study Group supported by the Research Grants for Cancer (12-15) from the Ministry of Health and Welfare*

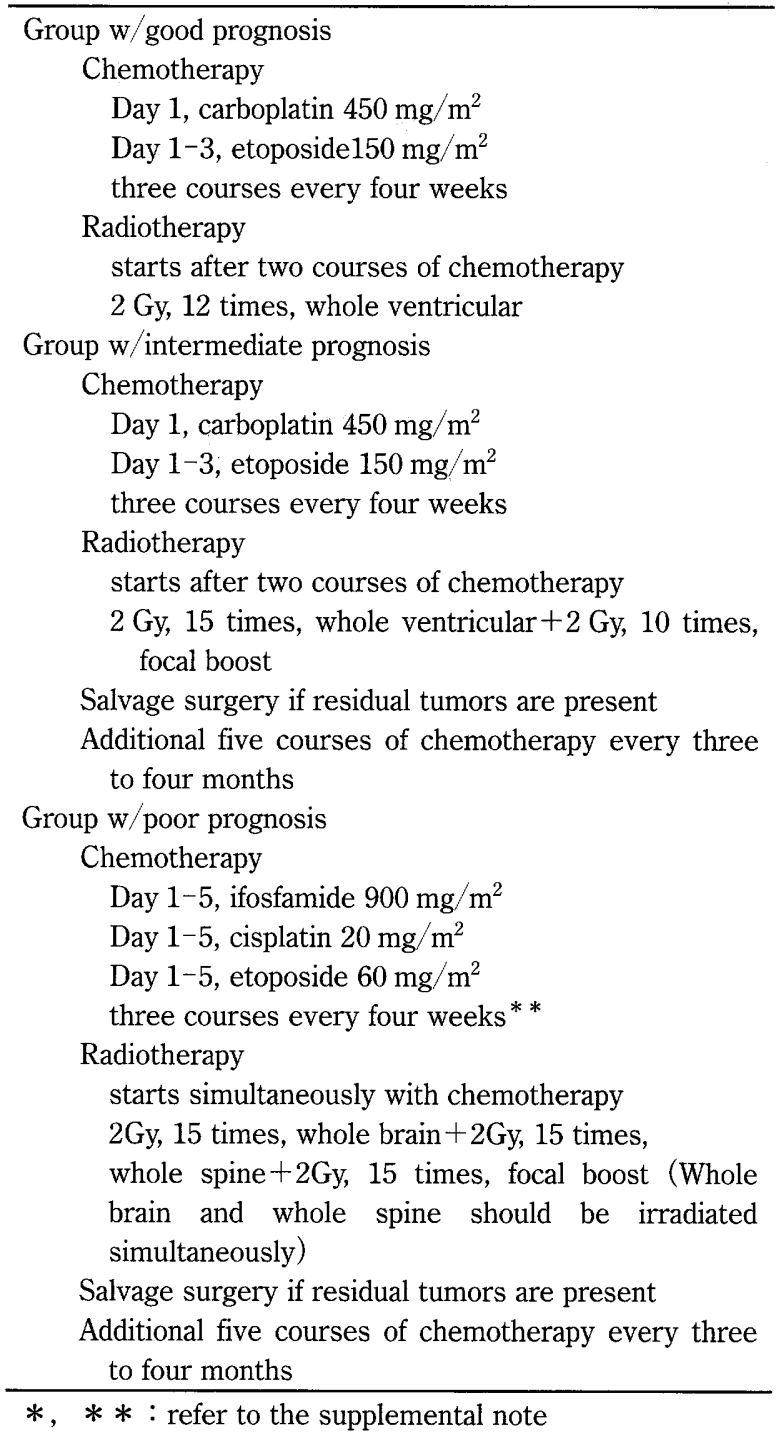

で行われた ${ }^{5)}$.中間解析において 5 年生存率 $98 \%$ (SFOP) ないし 98\%（SIOP）と報告されているが1)，再発症例の ほとんどは脳室内播種であったために，次のプロトコー ルでは全脳室照射を考慮すべきであろうと考察されてい る。米国では Children's Oncology Group による放射線照

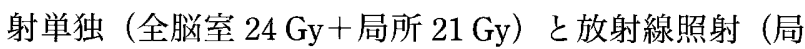
所 $30 \mathrm{~Gy}$ ) +化学療法 (carboplatin, etoposide, cisplatin, cyclophosphamide）を比較するランダム化比較試験 (ACNS0232) が計画されているが，本稿脱稿の時点では まだ実現していないようである (http://www.cancer. gov/clinicaltrials/COG-ACNS0232 に概略が記載されて
いる)。いずれにせよ欧米においても germinoma に対す る治療は全脳室照射十化学療法が主流となりつつある。

\section{予後中間群・不良群に対する治療}

厚生労衝省研究班のプロトコールでは, 予後中間群に 対しては全脳全脊髄照射は必要としないが, 全脳室照射 に加えて腫瘍局所への追加照射が必要であり, さらに維 持化学療法も必要であると規定し, 予後不良群において は全脳全脊骮道照射が必要で, かつ化学療法と同時に行う ことと規定している（Table 3）。この治療方針は, 始め に述べたような優れた治療成績の向上をもたらしたが, さらに最近の変更点として salvage surgery の導入が提 案された。これは熊本大学のグループが, 化学療法と放 射線照射による初期治療を行った後に残存腫崵を摘出す る必要性を指摘した報告に基づいている ${ }^{8)}$ ．11 例の悪性 肧細胞腫瘍（予後中間群を 1 例含む）をこの方法で治療 した結果, 5 年生存率 $90.9 \%$ という驚異的な数字が報告 され, 以降厚生労㗢省プロトコールにも取り入れられた。

\section{課 題}

今後の課題を列挙する.

1) Germinomaにおいては内視鏡手術が急速に導入さ れているが，その方針と役割を確立することが急務であ る.

$2 ）$ 本稿では触れなかったが, HCG- $\beta$ 産生 germinoma について，本当に予後中間群として扱うべきなのかどう か検討を必要とする。

3 ）予後中間群抢よび予後不良群においては, 厚生労働 省研究によって治療成績が大きく改善したが，しかし治 療成績のより一層の改善が依然として課題である. 照射 方法や化学療法の改良, また残存腫煬に対する salvage surgeryの成績の評価が必要である。

4）以上の上うな治療を行ったにもかかわらず，再発し た腫瘍に対する治療方針については，新しい化学療法の 導入も含めた検討が必要である。

\section{Table 3 付記}

* 本プロトコールは, 厚生労働省研究班開始後, 治療 成績をフィードバックすることにより徐々に修正が加兄 られてきた。例えば, 初期には germinoma の放射線照射 を局所照射のみで行った症例があったが, 照射野外の再 発が少なからず発生したため全脳室に統一された，予後 不良群においても, 初期には予後中間群のように化学療 
法を先行させる方法を採ったが，化学療法期間中に再発 する症例がみられたため，放射線照射を同時に開始する 方法に変更された。 また，germinoma と予後中間群にお いては一時期，術後残存腫瘍が径 $2 \mathrm{~cm}$ 以上，あるいは 照射終了時点で腫瘍が消失していない場合は carboplatin + etoposide ではなく ifosfamide+cisplatin + etoposide による化学療法を行うこととしていた時期もある が，2つの化学療法レジメンの間に治療成績に差がない ことが示された結果，この規定は削除された。

** 放射線照射，特に全脊髄照射を同時に行うために 強い骨髄抑制が出現することが多く，実際には 4 週間ご とに 3 回の化学療法を繰り返すことができない症例も 少なくない，その他，播種がある場合や年少者の場合な ぞ，放射線照射方法の変更が必要な場合もある．化学療 法や放射線照射には細かいノウハウもあるので，治療の 実際にあたつては経験のある施設に相談することが望ま しい.

本稿の要旨は，第 25 回日本脳神経外科コングレス総会において 発表した。

\section{文 献}

1) Alapetite C, Patte C, Ricardi U, Garre ML, Frappaz D, Brisse H, Kortmann R, Saran F, Nicholson J, Gaboriaud G, Calaminus $\mathrm{G}$ : Primary chemotherapy followed by focal irradiation for intracranial germinoma (ICG): Up-dated results of SFOP (CNS GCT-90) and SIOP (CNS GCT96). The First International Symposium on CNS Germ Cell Tumors. Kyoto, September 16-19, 2003 (abstract).

2) Aoyama H, Shirato H, Ikeda J, Fujieda K, Miyasaka K, Sawamura Y: Induction chemotherapy followed by lowdose involved-field radiotherapy for intracranial germ cell tumors. J Clin Oncol 20: 857-865, 2002.

3) Balmaceda C, Heller G, Rosenblum M, Diez B, Villablanca JG, Kellie S, Maher P, Vlamis V, Walker RW, Leibel S, Finlay JL: Chemotherapy without irradiation $-\mathrm{A}$ novel approach for newly diagnosed CNS germ cell tumors: Results of an international cooperative trial. J Clin Oncol 14: 2908-2915, 1996

4) Bamberg M, Kortmann RD, Calaminus G, Becker G, Meisner C, Harms D, Göbel U: Radiation therapy for intracranial germinoma: Results of the German Cooperative Prospective Trials MAKEI 83/86/89. J Clin Oncol 17: 25852592, 1999.

5) Bouffet E, Baranzelli MC, Patte C, Portas M, Edan C, Chastagner P, Mechinaud-Lacroix F, Kalifa C: Combined treatment modality for intracranial germinomas: Results of a multicentre SFOP experience. Br J Cancer $\quad 79: 1199$ 1204, 1999.

6) Duffner PK, Cohen ME, Thomas PR, Lansky SB: The long-term effects of cranial irradiation on the central nervous system. Cancer $\quad 56: 1841-1846,1985$.

7) Fujimaki T, Matsutani M, Funada N, Kirino T, Takakura K, Nakamura O, Tamura A, Sano K: CT and MRI features of intracranial germ cell tumors. J Neurooncol 19:217-226, 1994.

8) Kochi M, Itoyama Y, Shiraishi S, Kitamura I, Marubayashi $\mathrm{T}$, Ushio $\mathrm{Y}$ : Successful treatment of intracranial nongerminomatous malignant germ cell tumors by administering neoadjuvant chemotherapy and radiotherapy before excision of residual tumors. J Neurosurg 99: 106-114, 2003.

9）隈部俊宏, 日下康子, 城倉英史, 池田秀敏, 白根礼造, 吉本高志: 化学療法単独で治療した頭蓋内肧腫の再発. No Shinkei Geka 30: 935-942, 2002.

10）松谷雅生：脳腫瘍。東京, 篠原出版新社, 1996, pp.281304.

11) Matsutani $M$, Sano K, Takakura $K$, Fujimaki $T$, Nakamura $O$, Funata $N$, Seto $T$ : Primary intracranial germ cell tumors: A clinical analysis of 153 histologically verified cases.J Neurosurg 86:446-455, 1997.

12）松谷雅生：胚細胞腫瘍。山浦 晶編：脳神経外科学大系, 13. 小览脳神経外科. 東京, 中山書店，2004，pp.368375.

13) Miyanohara O, Takeshima H, Kaji M, Hirano H, Sawamura Y, Kochi M, Kuratsu J: Diagnostic significance of soluble $\mathrm{c}^{-}$Kit in the cerebrospinal fluid of patients with germ cell tumors. J Neurosurg 97: 177-183, 2002.

14）西川 亮, 松谷雅生: 松果体胚細胞腫瘍患者の高次機能. 認知神経科学 5：165-169，2003.

15) Rogers SJ, Mosleh-Shirazi MA, Saran FH: Radiotherapy of localized intracranial germinoma: Time to sever historical ties? Lancet Oncol 6: 509-519, 2005.

16) Roman DD, Sperduto PW: Neuropsychological effects of cranial radiation: Current knowledge and future directions. Int J Radiat Oncol Biol Phys 31: 983-998, 1995.

17) Sawamura $Y$, de Tribolet N, Ishii N, Abe H: Management of primary intracranial germinomas: Diagnostic surgery or radical resection? J Neurosurg 87:262-266, 1997.

18) Shikama N, Ogawa $K$, Tanaka $S$, Toita $T$, Nakamura K, Uno T, Ohnishi H, Itami J, Tada T, Saeki N: Lack of benefit of spinal irradiation in the primary treatment of intracranial germinoma: A multiinstitutional retrospective review of 180 patients. Cancer 104:126-134, 2005.

19) Shinoda J, Yamada H, Sakai N, Ando T, Hirata T, Miwa $Y$ : Placental alkaline phosphatase as a tumor marker for primary intracranial germinoma. J Neurosurg 68:710-720, 1988.

20) Wellons JC 3rd, Reddy AT, Tubbs RS, Abdullatif H, Oakes WJ, Blount JP, Grabb PA: Neuroendoscopic findings in patients with intracranial germinomas correlating with diabetes insipidus. $J$ Neurosurg $\quad 100: 430-436,2004$. 


\section{中枢神経肧細胞腫瘍治療の基本方針}

西川亮

中枢神経胚細胞腫瘍治療におけるポイントを概説した. (1)組織型確認のため手術は必須である. (2) Germinoma の手術は生検で十分かどうかについて，特に内視鏡の普及に対応した検討が急務である. (3)Germinoma の術後治療は, 全脳室照射に化学療法を併用する方向に向かっている. 背䯣照射は不 要である. 全脳照射でも治癒させることができるが, 放射線障害の可能性が否定できない. 局所照射 では高率に再発する. (4)Germinoma であっても化学療法単独では再発する. (5)予後中間群と不良群 に対しては, 初期治療後の残存腫瘍に対して salvage surgery を行うことによって治療成績が改善さ れる可能性が示された.

\section{脳神経外科ジャーナル＼cjkstart欦吕甬圈}

本誌 15 巻 4 号は, 第 26 回日本脳神経外科コングレスプログラムおよび抄録となります. 学会当日は抄録号は改めて用意いたしませんので本誌 4 号を持参して下さい.

\section{脳神経外科ジャーナル

\section{特別寄稿}

予防的脳神経外科手術の overview：医師の視点 東北大学大学院 森

総 説

情報誘導によるグリオーマ手術

頭蓋咽頭腫：治療法の選択と長期成績

頭蓋底䯣膜腫の治療オプションとピットフォール

一自然経過, 生物学的特性をふまえて一

\section{原 著}

ラトケ囊胞の長期治療成績と治療方針の検討

\section{症例報告}

眼窩部頭蓋骨海綿状血管腫の 1 例

日本大学

Traumatic trigeminal-cavernous fistula $の 1$ 例 那覇市立病院 百次

編集の都合上内容が若干異なる場合がありますのでご了承ください. 